\title{
An Unusual Patient Request
}

\author{
Mark Bernstein
}

Can. J. Neurol. Sci. 2009; 36: 398

How much is $\$ 250$ worth? Maybe it's just worth the memory it buys. Maybe it's a relatively cheap investment in feeling we've done a good thing.

It was the mid 1980's. I had finished my arduous residency training in neurosurgery and had recently started on staff at a large teaching hospital. I was bright-eyed and bushy-tailed, brimming with idealism and naiveté.

One of the surgical patients in my first six months was a lovely man, a recent immigrant from an African country where he had been an academic. Although he spoke with an accent, his grammar was impeccable and his vocabulary elegant. Here in his new chosen home, the land of opportunity, he was forced to do more menial work. He required a complex operation for a benign condition. As his neurosurgeon, especially a "new kid on the block", I was pleased when he had a good outcome.

There were one or two routine post-operative visits. Then, many months later, he requested an appointment with me. I feared he was returning due to complications from the surgery. However, he walked into my office looking just fine. He stood straight and tall and proud and was as well-dressed as usual. His beard was perfectly trimmed, as always.

I don't recall the exact words we exchanged, but he was in some kind of jam and needed some urgent financial help, shortterm, one-time. As he made his request, he seemed to be much less uncomfortable than I imagined I would have been had our situations been reversed. He did not divulge any details and I did not feel it my place to ask. I don't recall the words "loan" or "borrow" being used by either of us. He did not specify an amount. I asked him to return to my office in a week.

I did not want to ask a senior colleague for advice as I certainly knew what the answer would be. So I presented the dilemma to my wife. Not only was she my best friend and most trusted advisor, she was also the one person who could possibly have a stake in my decision. I was just starting on staff, my earnings were modest, we had debts, and our third child was on the way. She told me I should do whatever was in my heart. I had conflicted feelings - my instincts as a person told me to reach out to this man and help him. But my instincts as a health care professional screamed, "Are you mad? Get your boundaries straight, dude!" I slept on it for a few days.

Something about this man and his situation touched me and compelled me. I felt that he was honest and decent beyond question. The day he returned to the clinic I locked the office door and handed him $\$ 250.00$ in cash. I have no idea how I arrived at that amount. It seemed sufficient without being extravagant. He thanked me, said nothing else, and walked out. I made no documentation on his chart or anywhere else. The transaction was untraceable.

I don't know if I did it to be philanthropic or if I was just afraid of how I would feel about myself if I denied his request. Over the months and years, I never expected or received reimbursement or any news from him.
Why am I writing about this now? Over the last two decades, my wife and I raised three wonderful daughters and several canines. We have enjoyed our cottage and have traveled the world. I continue to enjoy a stimulating career in academic neurosurgery. But during all this time, I have occasionally thought of this man.

And then, over twenty years later, I saw him. I was driving alone on a beautiful early summer evening in an ethnic community rife with atmosphere and vibrancy. He was walking along the street and then running for a streetcar. There was no mistaking him - the same noble stature, the same handsome face, the same immaculate clothes. His beard was trimmed exactly as over twenty years ago, now with a gray streak in it.

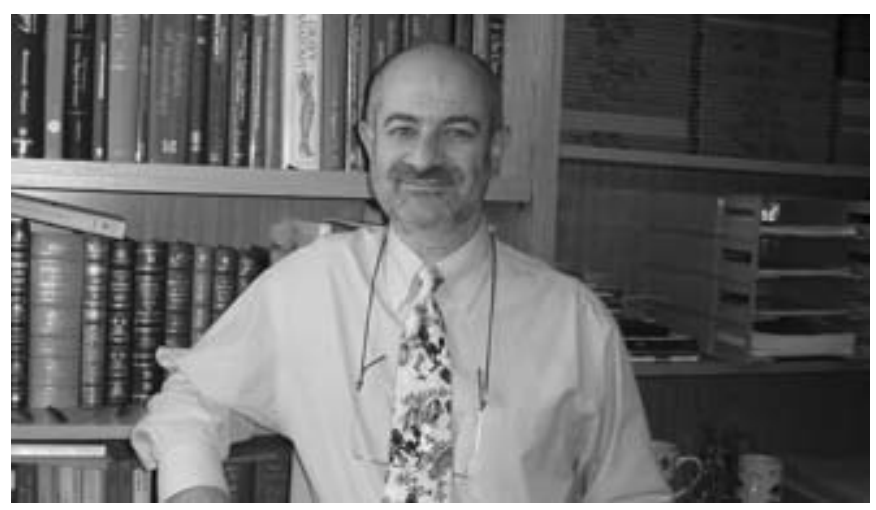

I stayed close behind the streetcar, following it. At each stop I looked to see who disembarked. After about ten stops, he got off. He paused briefly on the sidewalk to talk with an acquaintance. I pulled over to the curb about ten meters ahead of him. I turned my head and watched. I wanted to talk to him, to ask about his life, to make sure he was alright. I felt I had made some kind of investment in him many years before and was somehow responsible.

I sat and watched him walk away. I could not bring myself to get out of my truck and approach him. When he recalled who I was, he would certainly feel embarrassed. Again, just as two decades earlier, I don't know if my decision was out of kindness for him or to protect myself from potential discomfort. I drove home.

From the Toronto Western Hospital, Toronto, Ontario, Canada.

Received December 8, 2008. Final Revisions Submitted December 18, 2008. Correspondence to: Mark Bernstein, Surgery, Toronto Western Hospital, 339 Bathurst Street, Toronto, Ontario, M5T 2S8, Canada. 